a step towards the later wholly successful "Colossus" machine. It is believed that he was at least in part responsible for the securing of T.H. Flowers and his team from the Post Office Engineering Research Station at Dollis Hill for the cipher work at Bletchley Park.

After the war, Wynn-Williams returned to Imperial College and threw himself whole-heartedly into teaching work in practical physics in which his great inventive skills and warm personality led to outstanding success.

The author of this obituary experienced these personal qualities to the full during the three years in which he was associated with Wynn-Williams at Cambridge and cannot speak too highly of him as a coworker and friend, and for his help and encouragement.

F.A.B. Ward

\section{Vladislav Kruta}

MANY physiologists and historians of medicine in France, Great Britain, Czechoslovakia, and as far afield as New Zealand will be sorry to hear of the recent death of Professor Vladislav Kruta, MD, DrSC, past director of the Institute of Physiology of the Purkyně University in Brno, Czechoslovakia.

Born in 1908, his scientific career started in the early thirties at the Department of Physiology of Charles' University in Prague. From the beginning his interest was focused on the comparative physiology of heart muscle and on the effects of temperature on contractility. His research on the "Bowditch staircase" became a classic. His work brought him into close contact with French physiologists and especially with the school of Professor Lapique, where he spent a long period and where he also met his future wife. These contacts gave $\mathrm{Czech}$ physiologists access to the French and Western scientific forum: as a General Secretary of the Czechoslovak Biological Society he made this society a branch of the old and famous French Societé de Biologie.

As a convinced democrat, he left Czechoslovakia before the Second World War, spent a difficult period in France and was transferreci after the fall of France with the Czechoslovak troops to Great Britain. As a medical officer, he became attached to the famous 312th Squadron of the Royal Air Force, composed mostly of Czechoslovak airmen, a squadron which won its glory during the Battle of Britain, with the loss of many lives. For his couragenous conduct, Kruta was awarded one of the highest Czechoslovak military medals. Later in the war he was transferred to the Ministry of Social Affairs of the Czechoslovak Government in exile (in London) where he made use of his vast knowledge of the problems of nutrition to prepare the way in which the assistance of UNRRA should be made use of in his liberated home country. Czechoslovakia owes him gratitude for the generous contribution of UNRRA in reopening and restarting medical and biological research after the war.

In 1945, Kruta became one of the founders of the new medical school in the city of Hradec Králové. As with many other people who fought in the Allied forces in the West, he had been persecuted since 1948 and dismissed shortly afterwards from the Hradec Králové medical school, when it became a military medical academy under Russian supervision. He then took over the Chair of Physiology at the Purkyne University of Brno. In spite of many obstacles of a political nature he created there an excellent modern school of physiology, concentrating mostly on experimental cardiology.

His classical education and early interest in general history led him later to the history of medicine and mainly to the two great Czech protagonists of physiology Procháska and Purkyně. It was Kruta's great achievement to continue and complete the edition of Purkyne's Opera omnia, started before the War by the Prague histologist Prof. Studnička, and to write a monograph on both these great figures.

During the Prague Spring in 1968, Kruta deeply engaged himself in the democratization of life in Czechoslovakia. He was one of the 70 original signatories of the manifesto of " 2000 words" and after the Russian occupation, and in spite of pressure, he refused to recall his signature. This led to his immediate dismissal from the chair and from all academic activities. As a private person he continued his historical studies. His courageous and honourable life made him a lasting model to his compatriots and friends.

Jan Brod Otokar Poupa

\section{Robert Heizer}

Robert Flemming Heizer, who died on 16 July 1979 , at the age of 64 , was one of the best known and most outstanding archaeologists to have been trained and who taught at the University of California at Berkeley.

His contributions to his profession, to the scholarly world, to the public in general and to his University were continuous and at an extraordinary and prodigious rate and level of creative excellence that is rare, even in the most distinguished communities of scholars. He was the author of 24 books and nearly 400 scientific articles and monographs that express the remarkable breadth and wide-ranging interests of California's pioneer scientific archaeologist who believed that it is impossible to understand mankind or to formulate "laws" of culture without using the data of prehistorians.
Ranging from book-length treatments of the Olmec civilisation of Meso-America or the prehistoric rock art of California and Nevada (on which he was the acknowledged authority) to a study of prejudice and discrimination against Californian minorities under Spanish, Mexican and US regimes, or X-ray fluorescence analysis of obsidians and replicative experimentation in archaeology, his work also included excursions into such subjects as toxicology, geology, mineralogy, organic chemistry, pedology, demography, mathematics, architecture, history, limnology, law, conchology, zoology and economics, wherever he believed they could throw light on past human behaviour. His investigations at La Venta, not far from the Gulf of Mexico, as well as in the Valley of Mexico and Guatemala led him to develop a keen interest in the transport of megalithic monuments and the methods of erecting them which resulted in a brilliant piece of research on the origins of the Colossi of Memnon on the Nile.

The quantity and quality of his research and publication may in time tend to obscure his work and ability as a teacher. In this, however, he was equally successful and an inspiring lecturer at all levels of instruction. His teaching ranged from North American and Meso-American archaeology to California Indians, archaeology and society, and science in archaeology and he was equally as successful in field courses as he was in the classroom and in seminars. He was always available to talk with students, especially with any who came to discuss their original ideas.

Heizer's work is both the foundation on which systematic archaeology in California has been based and a contribution of major significance for the science of archaeology in general. This was recognised in the honours conferred on him: he was elected to the Society of Sigma Xi, was twice a Fellow of the Guggenheim Foundation, a Fellow at the Center for Advanced Study in the Behavioral Sciences at Stanford and was elected a member of the National Academy of Sciences in 1973. He received an honorary $\mathrm{ScD}$ from the University of Nevada in 1965.

Bob was the kind of scholar who will not be seen again for a long time. He was a great archaeologist to whom prehistory in the western states will forever be indebted. He was possessed of a rather rare sense of humour and could be extremely witty and good company. Critical of others, he was equally critical of himself and in some ways was a "loner". His friends remember him for his humour, kindness and generosity, his students for the way he shared with them the excitement of new discoveries in the field and colleagues and students alike for the magnitude and depth of his scholarship and for the stimulus that he gave to the discipline in general.

J. Desmond Clark 